\title{
«ЗНАЮТ, ОПАСАЮТСЯ, НО НЕ ГОВОРЯТ»: КОЛДОВСТВО У ЗАКАВКАЗСКИХ ДУХОБОРЦЕВ*
}

На основе полевого материала, собранного среди закавказских духобориев, в статье рассматривается «колдовской» дискурс, сформировавиийся в секте за два столетия, прожитые духобориами в отрыве от русского народа. Противоречие между народной традицией, которую они принесли из мест своего выхода, когда жили среди православньх в России, и религиозной доктриной, не допускавшей возможности общения сынов Божьих с нечистой силой, привело к тому, что тема колдовства была вынесена на периферию культурного поля и открыто не обсуждалась. В работе рассматриваются традиционные комплексы фольклорных сюжетов, дожившие в духоборческой среде до наших дней, и обращено внимание на широко известные сюжеты, оказавииеся неприемлемыли в их сообществе. Хотя среди духобориев не было людей, реально занимавиихся колдовскими практиками, в статье показаны механизмы «создания» образа колдуна. Потребность в таких людях исчерпывалась желанием односельчан возложить на них ответственность за проблемы и несчастья.

Ключевые слова: духобориы, религиозное учение, колдовство, фольклорный образ, русская мифологическая традииия

Начиная со второй половины XVIII в. ученые разных специальностей изучали представления русского народа о колдовстве и колдунах. С конца 1980-х годов, когда были сняты идеологические ограничения на подобную тематику, и до настоящего времени о колдунах и колдовстве написано и издано значительно больше литературы, чем за весь предшествующий период. Тем не менее, несмотря на многолетнее активное изучение, тема эта настолько многопланова, что заинтересованный исследователь всегда найдет в ней белые пятна, требующие его внимания. В данной работе речь пойдет о колдовстве и колдунах, об отношении к ним в религиозном

Иникова Светлана Александровна - кандидат исторических наук, ведущий научный сотрудник Института этнологии и антрополога РАН (Москва, Ленинский пр., 32a). Эл. почта: ovis2@yandex.ru. Inikova, Svetlana A. - Institute of Ethnology and Anthropology, RAS (Moscow, Leninsky prospect, 32a). E-mail: ovis2@yandex.ru

* Публикуется в соответствии с планом научно-исследовательских работ Института этнологии и антропологии РАН 
сообществе духоборцев ${ }^{1}$. Попытаемся вычленить комплекс представлений и определить, какое влияние оказала на них религиозная доктрина секты, какое место «колдовской» дискурс вообще занимал в жизни духоборцев.

\section{Колдовство в свете религиозного учения и воспитания}

Духоборцы являлись этноконфессиональной и локальной группой русских, создавших свое теократическое государство сначала в Таврии, а затем в Закавказье, жившее по собственным неписаным законам вплоть до конца 1920-х гг. Вера духоборцев во внутреннее откровение и в воплощение Сына Божия в плоти их руководителей создавала, казалось бы, удобную почву для расцвета мистики. Вопреки ожиданиям, во время экспедиций к закавказским духоборцам в конце 1980 - начале 1990-х гг. на вопросы о колдовстве информанты обычно отвечали незнанием или говорили, что бабушки что-то рассказывали, но они тогда не слушали, да у них этого давно нет. В результате общения в те годы сложилось впечатление, что этот пласт культуры у духоборцев представлен крайне слабо, что, впрочем, в свете их учения выглядело вполне логично.

Такое нежелание обсуждать тему колдовства много позже объяснила учительница - духоборка из с. Гореловка Богдановского р-на Грузии:

«Среди девчонок был разговор, но не боялись. Говорили с опаской “колдовка". “Ведьма" не говорили. Колдовство - это что она кому-то что-то сделала, в основном коровам или кто-то заболел. Так, чтобы страх перед ними... у детей - нет, а взрослые опасались. На кого думали - это обычные люди. Об этом не принято было говорить, особенно обсуждать эту тему. Делали вид, будто такого явления нет. Сказать, что это имело какое-то доминирующее значение - нет. Знают, опасаются, но не говорят. Эти люди не отделяются, не живут какой-то особенной жизнью. Они работают вместе» (ПМА 9: П.Н.К.).

Эта же собеседница вспомнила о своей поездке к родственникам в Крым, еще в 1980-е годы выехавшим из Гореловки, и, сравнивая, удивлялась, как там воспринимали тему колдовства: «Я в Крыму была, и там много родственников и учениц, и заговорили, и рассказали, что у них колдовство - это элемент жизни. У нас, чтобы это было частью жизни, - этого нет» (ПМА 9: П.Н.К.).

Тема, о которой не принято было говорить, как-то внезапно обнаружилась и актуализировалась к середине 1990-х - в 2000-е годы, когда эта, проживавшая в Грузии группа, фактически распалась и поодиночке, и партиями члены ее выезжали Россию. Переселение сопровождалось острыми конфликтами внутри сообщества.

${ }^{1}$ Секта духоборцев протестантского типа возникла в начале XVIII в. По указам Александра I (1802, 1804 гг.) духоборцы, подавляющее большинство которых были русскими, поселились и проживали в Таврической губ. обособленно от православных русских. После выселения их в Закавказье в 1841-1845 гг. по приказу Николая I, так же обособленно они жили среди армян и татар в Ахалкалакском и Башкичетском уездах Тифлисской губ. (совр. Грузия) и в Елисаветпольском у. одноименной губернии (совр. Азербайджан). В 1990-е и начале 2000-х годов практически все потомки духоборцев, за небольшим исключением, выехали в Россию. Жители с. Гореловка (Грузия) создали на исторической родине компактные поселения: с. Архангельское в Чернском p-не Тульской обл., пос. Мирный Клетнянского р-на Брянской обл., пос. Малый Снежеток мкр. Новый в Первомайском р-не Тамбовской обл. Очень небольшое число духоборцев еще остается в Ниноцминдском (бывш. Богдановском) и Дманисском (бывш. Башкичетском) р-нах Грузии, в Кедабекском p-не Азербайджана.z 
Грузия времен Гамсахурдиа и после него находилась в состоянии политической нестабильности и экономической разрухи, что очень тяжело сказалось не только на экономическом, но и на психологическом состоянии духоборцев. В этот период один за другим уходили из жизни старики, тяжело переживавшие развал общины и переселение. Именно они ранее создавали определенный климат в среде духоборцев и, как могли, старались поддерживать быстро исчезавшие границы между своим и чужим миром. В такой переломной ситуации, усугубленной внутренними конфликтами, усилились подозрительность, неуверенность в будущем, соперничество, и у части людей явственно обозначилась склонность к мистике, к разговорам о сверхъестественных явлениях и колдунах.

Духоборцы, переселившиеся в Тульскую область в конце 1989 - начале 1990-х гг. и в Брянскую в 1998 г., оказались среди русского православного населения, охотно обсуждавшего темы колдовства, паранормальных явлений и всего того, что в то время в избытке предлагали СМИ. Пожилые духоборки начали вспоминать рассказы своих бабушек и открыто говорить о собственных наблюдениях и переживаниях. Записанные нами материалы по колдовству главным образом получены от выходцев из самого религиозного и самого консервативного духоборческого села - Гореловки, переселившихся в те годы в Россию.

Высокая, по сравнению с жителями других селений, религиозность гореловцев вполне уживалась с их хорошей осведомленностью в вопросах колдовства, что давало жителям других духоборческих сел в Грузии право подозревать гореловцев в тайном использовании этих знаний: «В Гореловке самые колдуны и есть» (ПМА 1: Л.Т.Г.); «Это все больше в Гореловке было, а у нас как-то и не слышали» (ПМА 12: А.В.М.). Такое подозрительное отношение к жителям Гореловки можно расценить как отголосок былой вражды между малой (с. Гореловка) и большой (все остальные селения) партиями, разгоревшейся после смерти последней законной руководительницы Лукерьи Калмыковой или, как ее называли, «родимой Лушечки» (управляла сектой с 1864 г. и до смерти в декабре 1886 г.).

«Было бы неправильно думать, что все духоборческое общество в 1990-е годы вдруг заговорило о колдунах. Очень многие люди, в том числе пожилого возраста, продолжали на вопросы о колдовстве отговариваться незнанием и неверием: (Говорили у вас, что колдуны молодых портили на свадьбе?) «Ну, говорили, а там чума знает. Я не верю никому, не верю я, чтоб колдовство это было»; (Были разговоры, что колдуньи отбирают у коров молоко?) «Говорили, а правда, чи неправда! Может, корова захворает. Чума ё знае» (ПМА 9: А.В.3.); (В Ефремовке были колдуны? Кто-нибудь рассказывал, что они на перекрестках колдуют?) «Не слышала сроду, чтоб сказали: оберегайтесь, остерегайтесь. Про перекресток никогда не говорили ничего, никада не слыхала. Слышала, что есть колдуны, а чо они делают, не знаю. У него же на лбу не написано» (ПМА 9: П.И.Б.).

Некоторые, не отрицая самого явления, склонны считать, что оно по разным причинам ушло в прошлое, и теперь о нем вспоминают только старики, или, возможно, оно существует где-то, но не среди них: «Раньше свету же не было, они (колдуны. - С.И.), наверно, без свету это всё [делали]. А када уже стало электричество, они очень боятся этого» (ПМА 5: Д.П.М.); «С одной бабушкой из Ефремовки - Вагиной - лежала в больнице, и она говорила: “Э-э-эх! Скольки их тада было! Теперь их не дюже узнаешь, а тада они неграмотные, но были т-а-к-и-е!”» (ПМА 9: П.Ф.Б.). 
Истоки сдержанного отношения духоборцев к теме колдовства, по нашему мнению, лежат, прежде всего, в их религиозном учении о «внутренней церкви». В соответствии с ним духоборцы отвергали все внешнее в деле спасения души. Отсюда отрицание храмов, таинств, священства, обрядности, икон и проч. Человек создан по образу и подобию Божьему, а его душа - это образ троичного Бога, поэтому на молении духоборцы, кланяясь друг другу, поклоняясь божественному образу, сияющему в душе каждого ${ }^{1}$ О себе сыны Божьи, каковыми духоборцы себя считали, заявляли: «Мы язык свят, царское священие, люди обновления, и греха в нас нет» (Записка о разговоре с двумя духобориами 1874: 142), а в обществе таких людей просто не могло быть места колдунам, знающимся с нечистой силой.

Духоборцы, как и православные, однозначно считали колдовство тяжким грехом и говорили, что «колдунам, блядунам и безбожникам Бог грехи не прощает» (ПМА 3: М.П. С.). Колдовские «плохие молитвы» старейшая потомственная лекарка, пользовавшаяся у духоборцев очень большим авторитетом, назвала «чертовскими покликушками», и упомянула, и в одном из духоборческих псалмов говорится: «Мы уклонились от всех злых дел, от скачек, от плясок, от всех бесовских покликушек <..>». (ЖК 1909: Пс. 85). Совершенно очевидно, что слово «покликушки» родственно слову «кликуша» и оба слова являются производными от «кликать». В. Даль отмечал, что покликуша - это кликуша, одержимая болезнью, т.е. женщина, которая выкликает, в народе ее считали одержимой бесом (Даль 1994: т. 2, ст. 296; т. 3, ст. 620). Видимо, бесовские (чертовские) покликушки в понимании духоборцев - это какие-то выкликания, вызывания бесов, чем, собственно, и занимаются колдуны. Духоборцы от этого отреклись и зафиксировали в псалме, как догмат, и тем не менее в их среде на бытовом уровне продолжали существовать традиционные представления о колдунах и ведьмах, которые они вынесли из православных селений России.

Восприятие и отношение к колдовству и колдунам в среде духоборцев формировались на основе коротких и назидательных рассказов о жизни родимой Лушечки. Эти истории вместе с ее пророчествами и советами были не просто преданиями старины, как может показаться постороннему человеку, они являлись своеобразными инструкциями, которыми члены секты должны были руководствоваться в повседневной жизни. Эти премудрости в нужный момент припоминались, а иногда по мере надобности и сочинялись уважаемыми старичками, и таким образом общественное мнение направлялось в нужное русло.

Несколько таких рассказов можно озаглавить: «Лушечка и колдунья». Их сюжеты не отличаются особым разнообразием. Либо колдунья («нехорошая женщина, злая») подбрасывает на пути следования Лукерьи Васильевны хлеб, либо дает ей его в дорогу, иногда вместе с солью. Однако святая Лушечка знает о колдовстве, и в хлебе, действительно, оказываются лягушки, а соль превращается в червей. В одном из нарративов колдунья названа «любимой подругой Лушечки». Иногда колдунья сама

\footnotetext{
${ }^{1}$ Духоборцы с. Б. Проходы Харьковского наместничества в 1792 г. на допросе в Петербурге заявили: «Он (Бог. - С.И.) икону свою положил в душах наших. Опять сказано, что истинные поклонницы духом и истинною поклонятся» (РГИА). Духоборец из Солдатской Духовки Тамбовской губ. заявлял, что во время моления они поклоняются один другому и целуются, потому что «человек есть подобие Божие, почему они и думают, что они поклоняются самому Отцу и Сыну и Святому Духу» (РГАДА). И это давало им право говорить, что наедине с собой они кланяются «душе своей», поскольку она образ Божий (ЖК: Пс. 9. В. 6).
} 
оборачивается лягушкой ${ }^{1}$ и проникает в покои Лушечки, которая велит слугам вынести колдунью-лягушку на лопатке на улицу, при этом с состраданием говорит: «Тебя здесь раздавят, а у тебя трое детей». Женщины, особенно пожилые, пересказывают эти истории с благоговением перед памятью Лукерьи Васильевны. Приведем полностью один из нарративов на эту тему:

«Бабушка (бабушка информанта. - С.И.) у нее (Лушечки. - С.И.) была как служанка. Поехали они на Хуторок купаться, и скачет лягушка. Она и говорит, бабушка говорит: “Родимая Лушечка, гля, привязалася. - Кучер впереди сидит, а они тут сидят. - И не отхо́дя. Уж за Вихтаренковых выехали”. "Ну, нехай - говорит, - бегёть до кладбища”. - “А тада что с ней будя?” - “А что с ней будя?! У нее семь детей, чо с ней будя? Чо с ней надо сделать? Нехай идёть. Посигаить и пойдеть, раз у ней совести нету"» (ПМА 9: Т.М. К.).

Другая собеседница внесла уточнение: «Може, - говорит, - ее убить?» - «Не надо! У нее семь детей» (ПМА 9: П.Ф.Б.).

В этих рассказах Лушечка предстает не только прозорливой, но еще и милосердной руководительницей духоборцев. У нее нет ни страха перед колдовством, ни желания наказать колдунью, отомстить ей. Колдунья - всего лишь злой и бессовестный человек, умеющий оборачиваться лягушкой. В нарративах колдуньи не выглядят всемогущими, а опасность, от них исходящая, не кажется непреодолимой; скорее, они сами становятся уязвимыми, занявшись колдовством. Невозможно с определенностью говорить, сформировалась такая позиция еще во время проживания духоборцев в Таврии или в Закавказье, но уже одно то, что в этих назидательных рассказах существование колдовства в их среде все-таки допускалось, создавало почву для существования подобных представлений в их сообществе.

\section{Фольклорный и реальный образ колдуна}

Как выяснилось, среди закавказских духоборцев, главным образом проживавших в Грузии, бытовали типовые устойчивые комплексы фольклорных сюжетов на тему колдовства, укладывающиеся в рамки южнорусской традиции. Мужской персонаж низшей демонологии они называют колдуном, а женский - колдовкой, иногда колдуньей, хотя для южнорусского типа культуры характерно слово «ведьма». Духоборцы, еще в начале 1920-х гг. переселившиеся из Закавказья в Целинский р-н Ростовской обл., говорят ведьма, видимо, переняв это слово у приехавших в их села после войны украинцев и православных русских.

В среде духоборцев в обозримом прошлом не было людей, которые бы реально занимались магическими вредоносными практиками. Все колдуны и колдовки, о которых пойдет речь, считались таковыми на основании одних только подозрений. $\mathrm{Te}$, о ком начинали говорить в обществе как о колдунах, обычно навлекали на себя подозрения какими-то особенностями, т.е. тем, что общество считало отклонением от общепринятой нормы. Изредка случалось, что подозрения возникали благодаря стечению обстоятельств или даже злому навету. Заподозренным в колдовстве молва начинала приписывать характеристики фольклорных прототипов, причем, как пра-

1 Использование лягушек и жаб в магической практике для наведения порчи широко известно у русских, особенно в любовной магии. Ведьмы в восточнославянской мифологии все же скорее превращаются в жаб, а не лягушек, но у мордвы, а среди духоборцев была группа мордвы, есть персонаж оадзь - ведьма-лягушка. 
вило, не все, а только те, в которые сообщество готово было поверить. Изучая биографии колдунов, мы, таким образом, изучаем менталитет самого общества, которое формирует их колдовской образ.

Внешние физические данные (горбатость, сросшиеся брови, мрачный взгляд и т.д.) у духоборцев, в отличие от православных, не являлись причиной для возникновения подозрений. Наоборот, в разговоре многие духоборцы подчеркивали, что внешне это обычные люди, ничем не отличавшиеся от остальных.

Сложился определенный алгоритм формирования образа колдуна. Вначале одиндва человека отмечали какую-то особенность в поведении односельчанина или односельчанки, возникал слух, что тут что-то не так, а потом искали всё новые и новые свидетельства отхода его/ее от принятых норм. Из рассказов односельчан подчас трудно сделать вывод, что было первично в этом процессе. О двух таких колдовках информант рассказывала: «Как стадо коров выгоняют... у Гани сумочка постоянно при себе, и у Они зеленая сумочка. И стадо коров, и Оня за ним ходит по проулкам. Оня никогда ни с кем не разговаривала» (ПМА 4: П.Ф.Б.). Ганя была известной лекаркой, к которой приезжали посторонние люди, она же собирала лечебные травы. Оня с детства была нелюдима. Объединяло их то, что обе ходили по селу с сумочками, внутри которых могло быть что-то таинственное, и эта маленькая деталь окончательно завершала их непохожесть на остальных.

Процесс формирования репутации колдуна хорошо виден на примере биографий некоторых духоборцев, попавших в число колдунов и колдовок. Наиболее свежи воспоминания о жителе Гореловки Васе по прозвищу Шиш. Это был человек, далекий от религии, пьяница и босяк, который нигде не работал, семьи и хозяйства не имел, промышлял рыбалкой. Когда-то он был механиком на аэродроме и еще в те годы нахватался книжных знаний, мог поговорить на разные темы, а главное - таинственно о вещах таинственных, писал маслом портреты предков и мог смастерить что-нибудь почти художественное. Внешне он держался самоуверенно, а зачастую нагло, был способен на экстравагантные выходки и любил эпатировать ими своих односельчан. Его неоднократно видели ночью то в одном месте, то в другом, что вполне понятно, если учесть, что ночью он рыбачил на свет. Однажды в Гореловку приехал с гастролями гипнотизер. На сеанс пришли все, кто мог ходить, и всё шло гладко, пока в зал не ввалился Шиш. Он встал около сцены, не отрываясь смотрел на гипнотизера и периодически комментировал его действия. Гипнотизер заявил, что не может работать, и это только подкрепило подозрения некоторых гореловцев, главным образом, женщин, которые считали Васю колдуном и побаивались. Да и те, кто не считал, а таких было большинство, все равно старались не конфликтовать с ним, чтобы не ввязаться в скандал.

Его репутация способствовала тому, что некоторые в его действиях и словах подозревали скрытый смысл, которого там не было, и потом, если что-то случалось, припоминали их и были уверены, что именно на это он намекал ${ }^{1}$ и всё случившееся - дело его рук. Например, пришел на свадьбу и подарил самодельную рамочку для фото, естественно пустую, и сколько жили супруги, их семья, как та рамочка, оставалась пустой: детей они так и не нажили. На другой свадьбе пролез между молодыми, да еще обоих слегка стукнул по головам своей фуражкой, «вот и болеют обои всю жизню». Или рыбачил с лодки и крикнул идущей по берегу женщине, как она думает,

${ }^{1}$ Именно так в православном народе воспринимали слова старцев и стариц, странников и юродивых. 
будет ли ему удача. Она ответила, что будет. И Шиш в ответ ей прокричал: «Ну, и табе будет», а вечером ее очень сильно побил пьяный муж (ПМА 10: Л.В.А., Н.С.К.).

О своей репутации Шиш, конечно, знал. Пропив свои гроши, он незваным гостем заходил к кому-то в дом, - не ко всякому, а к тем, кто его побаивался, - и его кормили-поили, а когда являлся на свадьбы, - опасались выгнать, да и неудобно, не по-людски выгонять гостя.

Подозрение в колдовстве лежало и на сестре Васи - Любе Шишикиной: отчасти из-за брата, отчасти из-за ее увлечения сбором трав. И хотя все духоборки собирали травы для чая, Любе некоторые ставили это в укор: «Она все траву рвала. Нарвет и в паголёнки (голенища вязаных чулок. - С.И.), занавеску (передник. - С.И.), и пошла» (ПМА 4: П.Ф.Б.). Люба регулярно по воскресеньям и праздникам ходила молиться в Сиротский дом (в прошлом резиденция вождей, тогда и сейчас молельный дом), добилась того, что при отсутствии вокальных данных стала певчей, и вместе с группой певчих ходила по похоронам и поминкам, и, несмотря на все это, репутация у нее была плохая. Ее подозревали и опасались, а подтверждением всех этих опасений в глазах жителей Гореловки стали ее похороны. И уже задним числом в ней стали видеть причину всяких неприятностей, случившихся в некоторых семьях.

А похороны, действительно, произвели крайне тяжелое впечатление на всех гореловцев. По словам односельчан, все ожидали, что на ее похоронах что-то должно было случиться. Правда, говорили об этом уже после события, да и в 1990-е годы, когда рушилась прежняя спокойная и счастливая жизнь, состояние тревожного ожидания каких-то бед стало привычным для жителей духоборческих селений.

Когда процессия шла по селу на кладбище, один мужчина не удержал гроб, и тело выпало на землю. «И когда она выпала из гроба, все ахнули, и никто не хотел ее назад класть» (ПМА 10: Н.С.К.). Дочь ее плакала, кричала, но никто не решался подойти. Потом все-таки нашлись смельчаки. В общем-то, зрелище было жуткое независимо от веры или неверия в колдовство. Житель соседней Орловки, человек далекий от мистики, объяснил произошедшее просто: «Гроб упустили!? А гроб упустили потому что тот, который должен несть гроб, он у нас утром выпил пол литру водки и взялся гроб нести, и упустил. Не надо в это верить. Это все ложь!» (ПМА 10: И.А.С.).

Однако гореловцы обратили внимание не на то, сколько выпил этот человек, а на то, что после этого случая в их селе один за другим умерли восемь мужчин. Певчие, присутствие которых на похоронах и поминках обязательно, совершенно забросили свои хозяйства, пели и молились без отдыха.

Еще один колдун, о котором многие до сих пор помнят, - Тишуня по прозвищу Липатов из с. Орловка. В отличие от Васи и Любы, он был лекарем и брался снимать порчу, по крайней мере, все так говорили. У духоборцев в каждом селе были лекари, но репутацию колдунов время от времени получали лишь некоторые, кто брался снимать порчу или по слухам знал присухи, хотя никто и никогда из собеседников не подтвердил, что сам или знакомые пользовались подобными услугами. Такие лекари и лекарки занимали пограничное положение и их могли называть и так, и эдак, в зависимости от ситуации.

Молва приписывала Тишуне хвастливые слова: «Я умею заколдовать, я умею и отколдовать» (ПМА 9: П.Ф.Б.). И хотя далеко не все считали Тишуню колдуном, но даже они допускали, что он «что-то знал» или обладал какими-то способностями. Духоборка из Гореловки вспомнила о своих детских наблюдениях (начало 1960-х гг.): 
«Я девчонкой была. [Он] старик в то время уже был: с усами, - ему за 70 было невысокого роста, коренастый, довольно приятной наружности. Он какой-то родственник моей маме. А принято, если из другого села пришел в село, то зайдет к родственникам. Он зашел, и мама как-то засуетилась неестественно: “Садись, Тишуня, садись”. Села, разговаривает, но вся была какая-то сжатая. Он поел, чаю попил и ушел. И когда ушел, мама говорит: “Ой, Полечка, как же я спужалась”. У него какая-то сила была. Если он подумает про тебя плохо, сбудется. Видимо, чем-то он обладал. У него энергетика какая-то была. Говорили: ехали, и он толи дорогу перешел, толи глянул, и лошади уперлись и не пошли» (ПМА 9: П.Н.К.).

«Он чо-то знал. Он вреда не делал, - убежденно говорил гореловский духоборец, к отцу которого Тишуня приходил, но секунду подумав, неуверенно добавил, - a, может, делал... У нас худоба не водилась» (ПМА 9: А.А.Б.).

Тишуня, в отличие от Васи, не был плохим хозяином, ходил молиться по воскресеньям и даже считался в Орловке певчим - персонаж вполне благопристойный, хотя выпить любил. Да и называли его ласково, как принято у духоборцев называть уважаемых старичков. Духоборка из Орловки на вопрос о Тишуне, постаралась обойти слово «колдун» и передать, что слышала о нем: «Про него говорили, что он служил двум богам. Он был певчим и занимался черным делом. Бабушки соберутся, и я ихний разговор слышала, что он на кого-то обиделся, а ихняя свадьба была. И он сказал: “Хотите, я сделаю так, что вода будет кипеть?” И вот у них не было счастья, у тех молодых» (ПМА 11: Л.В.Т.). Далекий от мистики упоминавшийся выше орловский духоборец, живший по соседству и хорошо знавший Тишуню, уверял, что тот сам распускал слухи о своих способностях, а на самом деле не был ни лекарем, ни колдуном.

Большинство мужчин, получивших репутацию колдунов, сами приложили к этому старание, намекая в разговорах на свои особенные знания и возможности или стараясь пустить слух о таинственных ночных посещениях кладбища. Известен случай, когда мужчина из Гореловки, то ли стремясь прослыть колдуном, то ли желая пошутить над односельчанами, ходил ночью на кладбище с черной кошкой на плече. Осталось неизвестным, кто его там видел и кто разглядел ночью черную кошку, но слух пошел по селу, и его родные так и не смогли никого убедить, что это была просто шутка (ПМА 4: П.Ф.Б.).

У духоборцев, в силу их учения, до недавнего времени не было принято, как у православных, ходить на кладбище на Пасху, Троицу, в родительские субботы, или чтобы проведывать умерших родственников. Посещение кладбища ночью воспринималось односельчанами как неоспоримый аргумент в пользу того, что такой человек знается с таинственными силами темного мира. Представления духоборцев о том, что колдунам свойственно общаться с иным миром в присутствии черных кошек (ночью с Васей на рыбалку обычно ходили две его черные кошки), надо полагать, появились поздно, уже во второй половине XX в. под влиянием литературы и кинематографа.

Рассказывая о мужчинах-колдунах, духоборцы отмечали, что почти все они жизнь свою прожили плохо: в пьянстве, бедности, семейных раздорах. Об одном из них говорили: «А сами как жили? Пил, и ничего у них в доме не было, нет, чтоб как люди»; и о другом подозревавшемся в колдовстве: «И Василий Б-в, что учился (колдовать. - С.И.), тоже плохо жил» (ПМА 9: П.Ф.Б.). И действительно, заглянув в прошлое так называемых колдунов, увидим, что большинство из них были людь- 
ми пьющими, стоявшими на нижних ступенях социальной лестницы, и колдовская репутация давала им возможность хотя бы чем-то выделиться и почувствовать собственную значимость.

Женщины, наоборот, никогда не стремились прослыть колдовками. Они старались вести себя так, чтобы не дать повод для подозрений, и даже если совершали какие-то обряды, например, со скотом, то чтобы «никто не видал, а то начнут судить, что колдуешь» (ПМА 11: Р.И.С.) В женском сообществе к таким подозреваемым относились с сильной опаской, и хотя внешне этого старались все-таки не показывать, но такая репутация ограничивала не только коммуникативные, но и хозяйственные возможности прослывших колдовками ${ }^{1}$.

\section{Получение сакральных знаний}

Применительно к колдуну, реже - колдовке, духоборцы, как и православные, употребляют слово знал/знала. Так могли сказать и о лекаре/лекарке, и о человеке, высидевщем папоротник. Все эти люди получали сакральные знания из разных источников. Лекари передавали свои божьи молитвы по наследству. Высидевшие папоротник, - на памяти духоборцев таковым был только один старик - должны были пройти через невероятные испытания: провести много ночей (высидеть) в ожидании цветения папоротника, успеть схватить опадающий лепесток и вложить его в разрез, сделанный на руке, а потом превозмочь свой страх перед нечистой силой и суметь вернуться в село. Те, кто после этого оставался жив, становились всезнающими. И только колдуны получали свои знания из книги черной магии. Среди духоборцев слово чернокнижник является синонимом слова колдун, а вот женщин, подозревавшихся в колдовстве, чернокнижницами не называли, хотя о некоторых говорили, что и они учились по книге.

Обучение колдовству обычно происходило под руководством опытного колдуна, но возможно было пройти курс и самостоятельно. Говорили, что старые колдуны иногда специально старались дать ничего не подозревавшему человеку почитать черную книжку, увлечь его ею; кому-то книга досталась вместе с купленным домом, а кто-то просто выкрал ее из семьи колдуна.

Шиш и Тишуня, как и положено, в разное время учились у старых колдунов по книге черной магии, а потом успешно сдали экзамен. Это известный среди русских фольклорный сюжет, когда начинающий колдун должен показать свое умение пользоваться полученными знаниями и навести порчу на первого встречного:

«Один ходил учился колдовать. Ходил, ходил, а мать и сноха решили проследить, куда он ходе, где он бываить. Мать говорит снохе: “Ты сиди дома, а я пойду за ним”. Пошла, пошла, видить, куда он зашел. Она под окно. Они там читали, чи чо делали, а потом этот колдун говорит: “Ну, всё! Я всё передал, что знал, а ты пойдешь отсюда, и кто табе по дороге попадется, того и приберёшь”. А мать быстро домой как дала ходу. Пришла и снохе говорить: “Мене заваливай перинами, а сама двери не открывай”. Ну, и она так и сделала, эта сноха. Он орал, орал. В 12 часов как завищел! Когда

\footnotetext{
${ }^{1}$ У духоборок-соседок было принято в весенне-летний сезон договариваться и в течение нескольких дней отдавать удои от коров всех договорившихся сначала одной из них, потом другой и т.д. Это делали для того, чтобы быстрее собрать масло и сделать много сыра. Иметь дело с хозяйкой, подозреваемой в колдовстве, многие побоялись бы.
} 
утром вышли - шкурка растянутая на дверях висить. Разодрали нечистые, потому что он не смог, никто ему на дороге не встретился. Он сам калиновский. Это отец рассказывал» (ПМА 9: Т.И.С.)

В этот фольклорный сюжет духоборцы успешно вписали Шиша и Тишуню:

«Он (Вася - С.И.) еще молодой был, и еще Василий - сын Фени Б-ой. Они стали учиться у одного деда. Они учились у Шиша в доме, и кто первый попадется, они загубят этого человека. И попалась мать Шиша - Дуня. Она и была такая, ее всю вывернуло, парализовало» (ПМА 4: П.Ф.Б.).

И Тишуня, когда кончил учиться, «вся сяло там ревом ревели, и вся сяло были на замке уже. И он ходил, ходил по сялу. В какой дом при́дет, стучит, ему не открывают двери. Ну, вот, ему волей-неволей надо было идтить домой, уже 12-й час. И он пришел домой, постучал и жена вышла открыла ему дверь. И тут она заболела: он с себе свалил на нее. И тут же она заболела и вскорости она померла. Дети сироты осталиси. Если б он домой не пришел, если б ему жана не открыла в 12 часов, значит бы, его разорвали черти. Он кончил курс и должен кого-то загубить» (ПМА 6: Л.Ф.В.).

Духоборческая культура относилась к устному типу и ее носители долгое время были противниками обучения грамоте и чтения книг. В памяти стариков до недавнего времени сохранялась поговорка: «Научишься писать/читать, будешь людей кусать», т.е. такой человек воспринимался в обществе с большой опаской. Возможно, на этой почве если и не выросло, то укрепилось представление, что любой колдун учится по книге, которая ничему хорошему не научит.

Обучение по книге черной магии и у православных русских считается одним из способов превращения в колдуна. У духоборцев это единственный способ, поскольку только он предполагает осознанный выбор человека. У них отсутствуют представления о врожденных колдунах (человек просто не может родиться с черной душой), или о передаче колдовской силы перед смертью одним прикосновением к руке случайного человека. Перед смертью, по мнению духоборцев, колдун старается передать свою книгу. Никаких представлений о продаже души дьяволу, подписании с ним договора, а тем более снятии и топтании креста, который духоборцы и так не носили, у них нет.

Сдача экзамена - это первая встреча колдуна и нечистых - черньхx. Большинство считают, что колдун выученными молитвами вызывает черных, и они исполняют приказания. Духоборцы допускали, что если колдун не колдует, то тогда его «треплють нечистые». Видимо, когда-то у них существовали представления, что колдуны насыпают пшено, чтобы черные собирали его и оставили хозяина в покое. На эту мысль наводит рассказ старейшей духоборки из Гореловки, которой соседка посоветовала: «Теть Гань, ты знаешь чево? Худамент роете (фундамент для дома. - С.И.), пшено посыпьте кругом». Тетя Ганя на всякий случай пошла спросить старуху-лекарку, а та ей сказала: «Боже избавь пшено. Это, - говорить, - кто знает волшебству, пшено посыпать, чтобы они собирали, не лезли к няму» (ПМА 4: А.М.Г.) Некоторые полагают, что колдун с помощью этих особых «плохих молитв» действует вполне самостоятельно.

\section{Оборотничество}

В русском фольклоре колдуны, а особенно колдуньи/ведьмы, не знают ни пространственных, ни временных преград. Они летают и переносятся из одного места 
в другое с невероятной скоростью, собираются не только на Лысой горе, но и на деревьях, перекрестках. Они могут оборачиваться животными и неодушевленными предметами. Эти персонажи, как и бесы, способны менять свой облик и от этого кажутся особенно опасными для людей. Оборотничество в большей степени характерно для ведьм и в меньшей - для колдунов.

У духоборцев нам не встретились фольклорные сюжеты о летающих колдовках, а героинями рассказов об оборотничестве практически всегда оказывались безымянные колдуньи, хотя местом, где разворачивалось действо, иногда становились духоборческие села. В Калинино (бывш. Троицкое), расположенном недалеко от Гореловки, подковали какую-то колдунью-лошадь, но кто сумел это сделать, и кем она была - не припомнили. Было такое, что лекарь привязал приблудившуюся лошадь, а это оказалась женщина. Ему бы ее подковать, но «это надо знать. Это не каждый может» (ПМА 5: Д.П.М.). В стародавние времена, например, при Лукерье Васильевне, колдуньи оборачивались лягушками. Было и такое, что одна превратилась в колесо:

«Мужик идеть, но он тоже знал. Тогда ремней не было, учкора (шнурок, продернутый в поясе штанов. - С.И.) такие. В Писаревом проулке идеть мужик: колясо, обыкновенное колясо котится прям между ног. Он его прижмал, учкур вытянул из штанов. В тулу прихватил его и прикатил его домой, у лапаса (навес для повозок. С.И.) привязал. Утром встал: у нее из задницы и рота этот шнурок. Представь, коляco!» (ПМА 5: А.А.Б.).

Этот популярный фольклорный сюжет развернулся в духоборческой Гореловке, а конкретно - в Писаревом переулке, по которому, по воспоминаниям некоторых пожилых людей, в детстве и юности они опасались ходить в темное время. От жительницы Гореловки был записан рассказ о колдовке-лисе: «Бабушка с дедом шла вечером, и лиса перелезла им дорогу. А бабушка идет и молитву Божию читает. Лиса залезла на хату и говорит: “Ученая ты, девка". Это колдунья. Бабушка шла не оглядываясь» (ПМА 4: Т.Т.Б.).

Единственным реальным лицом, которому духоборцы приписывали способность оборачиваться лошадью, была всем известная жительница Орловки - тетка Васи и Любы Шишикиных. Возможно, отблеск ее колдовской славы отразился на ее племянниках, но установить это уже невозможно за давностью лет. Некоторые до сих пор еще помнят ее (умерла в 1960-е гг.). Собственно, никаких причин подозревать ее в колдовстве, а тем более в оборотничестве, не было, кроме того, что она много лет лежала в постели из-за болезни рук и ног и не могла ни ходить, ни даже самостоятельно есть: «Сестра бабки Дуни К-й в постели лежала. Она не ходила и ее с ложки кормили. Она жила в Орловке. Она была подкована подковами: руки и ноги. Она оборачивалась кобылой, а ее поймал знаток - дед Липатов (Тишуня. - С.И.). Шла белая кобыла, а он поймал и подковал ее. У нее дочь и семья была. Она под одеялом лежала <...>» (ПМА 4: П.Ф.Б.). Подков на ее руках и ногах никто, естественно, не видел, но по уверениям духоборок, только потому, что она скрывала их под одеялом.

Всё тот же орловский житель, не верящий в колдовство, на вопрос о подкованной колдунье, взорвался:

«Это все враньё! И энту женщину я знал, какую подковал. Она моей тетке свекруха. У ней прямой полиартрит, ей руки свяло. Бедная, как мучилась! 15 лет в постели лежала. Тоже, люди приугадывали, мол, нужно матку (центральную балку под крышей. - С.И.) приподнять, она помрёть. Она ж ни подняться не могла, ничего. Смерть 
пришла, - померла. Она побыла на водах в Аспинзе, ей помогло, а тут скоро Троица. Она хату помазала, пошпаровала (первая побелка после оштукатуривания. - С.И.), а было холодно. И всё: свалилась» (ПМА 10: И.А.С.).

О таких как Тишуня, который сумел поймать колдовку-лошадь и подковать ее, православные собеседники сказали бы «сильный колдун», но духоборцы не разделяли их на сильных и слабых, хотя объективно такое представление о разных возможностях колдунов существовало. Никому бы в голову не пришло рассказывать, что Вася Шиш тоже кого-то подковал. Он никого не лечил, порчу не снимал, т.е. не был такой же знающий, как дед Липатов. Кроме того, Вася здравствовал еще в 1990-е годы, а Тишуня умер в конце 1960-х или начале 1970-х годов, и бо́льшая временная дистанция, отделявшая рассказчиков от времени его жизни, давала им право в значительно большей степени мифологизировать его образ.

\section{Вредоносная деятельность}

Предназначение колдунов, как известно, заключается в нанесении вреда (порчи) окружающим их людям. Эта деятельность могла быть направлена на людей и на их хозяйства. Применительно к ее результату, как и остальные русские, духоборцы использовали слово сделали, сделано. Под порчей людей духоборцы понимают всё то, что может отнять счастье и покой, причинить физическое и душевное страдание, т.е. существенно испортить человеку жизнь и, наконец, привести к безвременной смерти.

Особенно притягательными для колдунов были свадьбы. Поскольку духоборцы имели большую родню и многолюдные свадьбы, то подозреваемые в колдовстве за свою жизнь перебывали не на одной из них. Раньше, по воспоминаниям старых духоборок, последствия порчи проявились уже в первую брачную ночь и исключительно у молодых мужей, но со временем акценты сместились и разговоры о порче начинались спустя годы после свадьбы, когда в семье что-то разлаживалось, а на свадьбе, как выяснялось, был кто-то из односельчан с плохой репутацией. Так, Люба Шишикина присутствовала на свадьбе у своей родственницы, без приглашения лезла помогать заносить в дом постель молодой, а потом вдруг заметили узелок, лежавший посреди спальни. Что в нем было, никто не посмотрел - побоялись. Возможно, он входил в приданое и выпал оттуда, но его вынесли на лопате, спрятали во двоpe, а утром узелка не оказалось. Развод супругов через 20 лет, уже после Любиной смерти, родственники расценили как результат наведенной ею в тот вечер порчи (ПМА 10: Т.С.Ч.).

Вася Шиш жил на одном подворье с Любой и ее семьей, но в разных домах. У сына Любы Михаила была свадьба. И вот, все гости разошлись, молодые и Люба легли спать, а Шиш ночью стал ломиться к ним в дом. Невестка открыла ему дверь: «И с тех пор она болела и умерла молодой. И Миша тоже уже умер. У этой Любы четверо детей, и все умерли до старости. И никого из них в живых» (ПМА 10: Т.С. Ч.).

Тишуня Липатов был приглашен на свадьбу к племяннице своей жены, и во время даров, когда молодые стояли перед гостями, держась за руки, он попытался пройти между ними. Они его не пропустили, и уже тогда Тишуня пригрозил, что это им еще припомнится. В их семье трое детей один за другим рождались с физическими дефектами и, пожив несколько лет, умирали, пока несчастную женщину не вылечила лекарка из армянского селения. 
Колдуны ни во что не ставили очень высоко ценимые в сообществе духоборцев семейно-родственные отношения, для них не существовало своих и чужих, потому что они, в отличие от других, лишены человеческих привязанностей. В Калинино колдунья, по словам рассказчицы, просто так наводила порчу на детей своего брата:

«Тетка - мамина сестра - за Мишей Горьковым была. Так она девять детей положила. Четыре года порастёть и умирает. Потом пришла цыганка, а она была беременная. Цыганка говорить: “Ты хочешь, чтоб у тебя дети были? Ты слушай, чо я тебе скажу”. И она ей наговорила узелок и сказала, когда роды начнутся, будут гореть дрова, и вот этот узелок должна выбросить в печь. “И увидишь, кто это тебе делает”. И так и получилось, что разожгли дрова и начались роды. Она бросила и подойдеть, а там голосють, просють: “Не губи семью”. Голоса всякие. И муж подошел и хватил узелок (из печи. - С.И.), а все-таки она его выбросила. И оказалось, это была его сестра и ее муж. Они сразу пришли к ним. Первого она родила, у него голова была скворца, а тело мыша. Два часа с половиной он был живой, в воде плавал. А потом у нее опять начались схватки, и она родила сына, а того закопали. И потом у нее еще трое родились, и все были живы» (ПМА 9: Т.И.С.). После этого муж этой женщины выгнал сестру и прекратил общаться с ней.

Колдовки проявляли интерес не только к свадьбам, но и к похоронам. Они старались улучить момент и украсть что-нибудь из одежды, снятой с покойного для использования ее в своих целях. Видимо, раньше этим они и ограничивались, но услышав в конце 1990-х годов по телевидению или где-то прочитав об энергетических вампирах, некоторые заговорили о том, что колдуньи подпитываются энергией от мертвых, поэтому и ходят по похоронам. В качестве примера одна из собеседниц вспомнила, как сама когда-то наблюдала необычные явления: в день похорон с приходом колдовки в дом, где лежал покойник, начал шевелиться платок, расстеленный на подоконнике; другой раз с приходом на похороны другой подозреваемой приподымались ломтики хлеба в хлебнице, стоявшей на столе. Уже в Архангельском (Тульская обл.) толи лекарку, толи колдовку однажды поймали в тот момент, когда она подкинула (по ее словам - уронила) в гроб узелок с землей. Родственники покойного отругали ее, однако из уважения к возрасту разрешили ей и далее присутствовать на церемонии (ПМА 9: П.Ф.Б.).

Духоборцы с легкостью допускали, что своими бесовскими молитвами колдуны и колдовки могут наслать по ветру болезни, например, на зажегшийся в доме вечером свет они посылают огника - красную сыпь на лице; могут подбросить на перекрестке какую-то вещь, через которую поднявший возьмет на себя хворь; могут отнять след или закопать что-то у порога, сделать так, что в живот попадет лягушка или заведется червяк-алкоголик и тогда человек превратится в алкоголика. Болезни, лягушки и червяк-алкоголик - это все нечисть, которая может завладеть телом, и ее надо изгонять, т.е. отлечивать молитвами, но колдуны, в представлении духоборцев, не могут вселять в человека бесов, которые завладевают его телом и душой.

Духоборцы не читали Св. Писание и не знали обо всех многочисленных изгнаниях бесов, которые совершал Иисус Христос и его ученики. В их учении силы зла бесы, нечистые духи и антихрист(ы) - представлены более чем скромно и очень расплывчато, как некие абстрактные образы зла - богоотступники без какой-либо 
конкретизации их деяний ${ }^{1}$ Фольклорный образ черта, которого старались лишний раз не поминать, существовал где-то на периферии сознания. Духоборческая религиозная доктрина, делавшая уступки русской мифологической традиции, в этом вопросе была непреклонна. Представления о Божественном образе в душе духоборца, о том, что человек - храм Божий, оказались несовместимы с представлениями о вселении бесов, которые говорят на разные голоса, управляют поведением человека, а потом после его смерти забирают его душу. У духоборцев не было одержимых нечистым духом кликуш и, соответственно, всего того большого корпуса сюжетов, связанных с этим явлением, как у православных русских.

Если порчей людей занимались преимущественно колдуны, то нанесение хозяйственного ущерба было прерогативой колдовок. Они могли отнять сnарину - хозяйственный успех, испортить скот, главным образом коров, однако ни о каких заломах на полях, запирании небесной влаги (дождя) у духоборцев речи не было. Раньше, по словам рассказчиц старшего возраста, под праздники на сараи вешали замки и закрывали скот, чтобы лекарки/колдовки его не попортили (ПМА 1: Л.Т.Г.). Если же такое случалось, то приглашали лекарку, чтобы она отлечила. С колдовками, заподозренными в порче коровы, некоторые хозяйки могли начать выяснять отношения. Бабка Даньшина в с. Славянка (Азербайджан) была известна тем, что только глянет на корову и та не заходит во двор. Хозяйки таких коров ходили к ней и могли отругать, после чего, как рассказывала одна из них, «бабка пришла, что-то почитала, и корову отпустило» (ПМА 7: Г.Т.С.).

В Славянке было особенно много желающих попользоваться чужим молоком: «Колдуны были. Бабки рассказывали. Книги были старинные и учились. Пойдешь корову доить, а молока нема: колдуны забрали. К бабушке придут и жалуются. Она отлечивала» (ПМА 7: А.Н.П.). В Гореловке такие тоже были. До сих пор вспоминают некую Длиннуху (прозвище из-за высокого роста), которая «на прогоне коров доила. Своих не было, а молоко было» (ПМА 9: П.Ф.Б.). Случалось, как рассказывали духоборки, хозяйка даже заставала колдунью в хлеву, причем лица не видела, но замечала, что та была в белой одежде. Колдунья тут же исчезла, а вместе с ней и молоко у коровы. Правда, через два-три дня оно появилось (ПМА 7: В.Г.А.).

Среди духоборок широко известен фольклорный сюжет о колдунье, которая, вытащив сучок или колышек из дырки в столбе, набирает себе в ведра молоко от чужих коров:

«Старушка мне рассказывала, сядем завтракать, она чего-нибудь рассказывает. Одни люди были. Снохи у них были. Одна сноха один день управлялася, другой день другая сноха управлялася. Ну, може, там и третья сноха была, не знаю. Первая сноха пойдеть управляться, у ней много молока. Вторая сноха идет на второй день управляться, у ней молока нету. Ну, и уже тут старики стали ее недолюбливать: не может она чи доить, чи кормить, чи чево. Мало у ней молока. А тада как у них дело получилося: или ента сноха подглядела, вторая за этой, за первой, чаво она там делает. Она пойдеть там доить коров и сучок там в столбе. Вытащит этот сучок, и молоко текёт у ведро с соседских коров. Напустит, принясеть, молока много у ней.

${ }^{1}$ Из 373 псалмов, собранных В.Д. Бонч-Бруевичем и опубликованных им в «Животной книге духоборцев», только в восьми есть слова «бес», «бесовский» (пс. 85, 88, 112, 224, 241, 275, $278,339)$, в четырех - «нечистые духи» (пс. 100, 362, 364, 365) и в семи «антихрист» (пс. 82, $90,94,126,132,140,143)$. 
А эта с коров чо надоить? Та, ента невестка, сколько разов так, а тада до того у них дело дошло, что она не стала молчать, и чаво у них дальше получилось, неизвестно» (ПМА 6: Л.Ф.В.).

Выражение «отнять молоко у коровы» могло означать не только его количественное сокращение, но и отсутствие съема: «Вы собираете, собираете и ничего не соберете: ни масла, ничего, хотя корова доится как всегда (ПМА 5: Д.П.М.).

Существовал способ узнать из какого молока сделано масло: «Старичок (свекор С.И.) рассказывал, приходит дед к ним, и у него всегда ножичек. Пришел к их деду. Масло дали. Он своим ножом порезал и стал есть. И сказал, что он всегда масло испытывает: если ворованное, то на ноже будет кровь. Но надо же еще и молитву знать» (ПМА 9: П.Ф.Б.).

Не верящие подобным историям женщины из Гореловки со смехом рассказывали о своих родственницах, которые видели происки колдовок там, где сами совершили оплошность: «Другой раз наша Малашка и Танькой не загнали ли Гани С-ой корову? Они (коровы. - С.И.) так похожи. Ее гонють, она не идеть. Они ее гонють, она не идеть. Ну, и всё: чо-то тут сделано! Тут Малаха наша сразу: “Тут чой-то сделано”. Ганя гоне их корову, и всё: и колдун ушёл» (ПМА 6: М.П.К.).

Последние лет 30 молоко у коров никто не ворует. Как-то само собой всё прекратилось: да и коров теперь мало кто держит.

\section{Распознавание колдунов и средства защиты}

У пострадавших от колдунов всегда возникает естественное желание узнать, кто «сделал», кого надо остерегаться. В старину колдунов видели «святые и праведные родители», т.е. вожди духоборцев, а также люди, получившие свои знания благодаря цветку папоротника. Среди русских широко известен способ заставить колдовку явиться в тот дом, где она наколдовала, и тем выдать себя. Для этого надо было сжечь или поставить в горячую печь то, чего коснулась ее колдовство. Старые духоборки, переселившиеся в Ростовскую область в 1920-е гг., вспоминали и рассказывали молодым, как они поступали в Закавказье, если кто-то воровал у коровы молоко: «Вот, надои, налей молока на сковородку и поставь в печь. Как закипить молоко на сковородке, кто тибе сделал, он придеть». И, по словам очевидицы, тогда еще девочки, к ним пришла женщина, о которой все говорили, что она ведьма (ПМА 8: А.А.Р.) Так же женщина из Калинино, похоронившая девять детей, во время родов сожгла в печи наговоренный цыганкой узелок, и виновница явилась.

Чтобы узнать, кто им сделал, духоборки обращались за помощью к цыганкам, армянкам, азербайджанкам, т.е. к людям иной этнической принадлежности, которые обладали некими, присущими только представителям этих народов, тайными знаниями. К гадалкам потихоньку ходили в годы войны, чтобы узнать о судьбе близких, ушедших на фронт, и чтобы узнать, где искать пропавшую корову или овцу, или спросить, кто сделал. Услугами гадалок часто пользовались в 1990-е годы, когда решался вопрос о переселении в Россию.

Арсенал средств превентивной защиты от колдунов и колдовства у духоборцев невелик, если сравнивать их с православными. У них нет такого универсального оберега, как крест и крестное знамение, в их домах нет икон, у них не принято хранить в укромном месте или вешать на стену молитвы от нечистой силы и колдунов. Издав- 
на духоборцы употребляли такое традиционное для русских средство от колдунов и нечистой силы, как осина: при строительстве дома некоторые забивали осиновые колья по углам фундамента, «чтобы колдуны не прикасались» (ПМА 4: У.В.Г.); иногда «бабки осину втыкали в порог гдей-то. Были такие бабки» (ПМА 9: А.В.3.). Бывали такие разговоры, что надо втыкать в дверь иголки, чтобы колдун не пришел, но вот делали это или нет, осталось неизвестным. Духоборцы Дманисского р-на (Грузия) и Кедабекского р-на (Азербайджан) и сейчас где-нибудь над входной дверью прикрепляют веточку синеголовника. Так же делают и соседи-азербайджанцы.

У православных сильной молитвой от всяких бед, в том числе и от колдовства, считается 90 псалом «Живый в помощи Вышняго ...». Его от разных несчастий читают и духоборцы, но в искаженном виде: «Живый Богу помощи вышняго ...» (ЖК 1909: Пс. 278). Некоторые духоборки старшего поколения знали заговоры, направленные именно против колдунов и колдовства и при случае шептали их. Приведем один такой в качестве примера:

«Господи, благослови. Колдунья, не колдуй мене, а колдуй сама себе. Колдунам, колдуницам, еретникам, еретницам, каверзникам, каверзницам, - всем вам, нечистым духам, срату в пазуху, а с пазуху - в рот.

Зелье вам в зелье, а кореньи ваши в огонь, чтобы они погорели, языки ваши ожелезнели, а зубы ваши стиснулись, ума нечистой силы урухнулись (ворухнулись), у ваши сердца обернулись, у вашу черную кровь, у ваши легкие, печень, да и будет с вас. Ангел придет, стихи поёт. Бог бы наш избавит нас ото всех скорбей и болезни, ото всей печали. Аминь, аминь, аминь» (ПМА 2: М.А.Т.).

Духоборцы говорят, что колдовок надо проклинать, чтобы они не смогли ничего сделать. В качестве примера жительница Гореловки рассказала, как проклинала колдовку (за глаза) ее очень верующая бабушка: «Ух, будь она, провались пропадом, проклятая!». Существует мнение, особенно среди людей среднего возраста, что «не надо бояться и тогда все это отстает» (ПМА 11: Л.В.Т.). У духоборцев не было принято складывать пальцы рук в фиги при встрече с колдунами и колдовками, а тем более устраивать скандалы и самосуды.

\section{Смерть колдуна}

Как и православные, духоборцы полагают, что колдуну тяжело умирать, особенно если он не передал свою черную магию. Его грехи и знания не дают ему спокойно отойти в мир иной. Колдуны долго мучаются перед смертью, ревут так, что на улице слышно, затихают и вновь оживают. Однако при расспросах о смерти тех, кого еще недавно подозревали в колдовстве, выяснялось, что ничего примечательного никто не заметил. Разве что Тишуня «умирал на пече корчажкой, и никто не видал. Уж на другой день сын кинулся, открыли дверь, а он на пече корчажкой лежить. Вроде бы у него половина спины или живота сгорело на пече. Печь топилась. Его чуть обмыли и похоронили» (ПМА 6: Л.Ф.В.). Но это рассказывала женщина из другого села, а сами орловские духоборцы ничего особенного не припомнили. «Подкованная» колдунья из Орловки умерла тихо, хотя пока она 15 лет лежала в постели, некоторые односельчане предлагали приподнять матицу. Правда, никто из духоборцев не вспомнил, чтобы действительно когда-нибудь поднимали или хотя бы имитировали подъем матицы. Жительница Гореловки рассказала об односельчанке, которая ле- 
жала без сознания восемь дней, а на девятый померла. На работе после ее похорон стали обсуждать это событие:

«Одна говорить: “А вот Настя так долго хворала, Попова. Пока матку не подняли, она и не умерла. Как матку подняли, она и умерла”. А мне так чудно над ней стало. У ней дом стандартный (современный, без матицы. - С.И.). А я говорю: “Алён, у них дом стандартный. Матка где?!” Она мне говорить: “А ты хорошо подумай. У них матки нема на дворе?” Я молчу. “Как нема?! В сарае, в амбаре матки”. Я говорю: “А что, в амбаре поднимали?” - “Ну, вот. А ты не веришь”. Може, это брехня всё, не знаю» (ПМА 9: А.Е.К.).

Настю эту в колдовстве не подозревали, но считали поднятие матицы универсальным средством для ускорения процесса. Иногда затянувшаяся агония наводила окружающих на мысль, что здесь что-то не так, что все это неспроста. Подозрение, которое давно пало на лекарку Ганю в Архангельском, не все односельчане разделяли, однако умирала она долго, и это склонило некоторых к мысли, что подозрения были не напрасны: «Умирала она... рев был сильный. Она так ревела. Мне тоже казалось, что она не колдунья» (ПМА 9: А.А.Б.).

Некоторые духоборцы старшего поколения слышали, что колдуну в могилу надо вбивать осиновый кол, чтобы он не мог встать и ходить: «Это колдун умирает, ему прибивають. Бывает, мертвый ходе. Надо кол осиновый забить прям в могилу» (ПМА 9: М.К.Т.). Мертвые могут вставать и ходить, если у них какая-то обида на живых или если мертвый «сам нечистый был», т.е. колдун, однако никто не вспомнил, чтобы когда-нибудь использовали это средство.

Выслушивая невероятные истории о колдунах и порче, естественно возникал вопрос, а не было ли страшно жить рядом с такими людьми, отдавать замуж в семью колдуна дочь или брать к себе в дом невестку из такой семьи. Гореловский духоборец, присутствовавший при этих беседах, дал ответ: «Не было так сильно... так страшно не было» (ПМА 11: Н.К.С.). Этот же духоборец с сожалением говорил о Васе Шише: «Он просто запутался. В народе о таких говорят “любошный” (бедный, несчастный. - С.И.)» (там же). Пожилая духоборка, сын и невестка которой, по ее словам, пострадали от колдуна, пожалела не только их, но и его: «Он мучается сам и людей мучает» (ПМА 10: Л.В.А.), т.е. это нехорошие, зловредные, но в тоже время заблудившиеся между добром и злом несчастные люди, как те самые колдуньи-лягушки, которых когда-то пожалела родимая Лушечка.

$* * *$

Из мест своего первоначального проживания среди православных в России духоборцы принесли вначале в Таврию, а потом в Закавказье традиционные русские представления о колдунах и колдовстве. По своим религиозным убеждениям духоборцы являлись тем сообществом, в котором, если следовать догматам их веры, не должно быть даже допущения самой возможности существования колдовства в их среде. Тем не менее, представления о нем сохранились у потомков духоборцев до наших дней, правда, со временем часть наиболее неприемлемых для духоборцев сюжетов отсеялась.

Фольклорные образы колдуна и колдовки, существующие у современных духоборцев, не имеют целого ряда черт, которые до ныне сохраняются в рассказах ин- 
формантов из южных и центральных областей России, причем черт, которые делают колдуна особенно опасным: колдунами не рождаются, колдун и колдунья не продают душу дьяволу и не подписывают с ним договор, они не летают по ночам и не собираются в определенных местах, у них нет главы, они не могут передать свое колдовство прикосновением, это осознанный выбор, и главное, - они не могут вселить в человека бесов и загубить его божественную душу. Они не всесильны и часто сами жалки и несчастны.

В число подозреваемых в колдовстве, как правило, попадали люди, в чем-то отошедшие от принятой в социуме нормы, часто с какими-то нравственными изъянами. Обычно на них возлагали ответственность за проблемы и неприятности, которыми так богата жизнь, но очень часто их самих эта роль как раз и устраивала, поскольку хотя бы немного приподымала в собственных глазах.

Духоборческое сообщество всегда было четко структурированным с жестким распределением социальных ролей. Во главе его до 1887 г. стоял лидер, в котором воплотился Сын Божий, окруженный авторитетными в религиозных вопросах старичками. И после пресечения династии вождей, в каждом селении религиозно-обрядовой жизнью руководили старички и певчие. Для колдунов в этом обществе не было социальной ниши и никакой другой роли, кроме «козлов отпущения», им не могло быть отведено. Противоречие между укоренившейся в сознании духоборцев народной традицией и их религиозной доктриной привело к тому, что тема колдовства была вынесена на периферию культурного поля и открыто не обсуждалась.

\section{Источники и материалы}

Даль В. Толковый словарь живого великорусского языка. В 4-х томах. М.: Прогресс, 1994. T. 2,3 .

Животная книга духоборцев / сост. В.Д. Бонч-Бруевич. СПб., 1909.

Записка о разговоре с двумя духоборцами архимандрита Евгения, впоследствии митрополита Киевского // Чтения в Обществе истории и древностей российских. 1874. Кн. 4 (октябрь-декабрь).

ПМА 1- Полевые материалы автора. Экспедиция в Богдановский р-н Грузии. 1988 г. (информант: Л.Т.Г. 1909 г.р. Ефремовка).

ПМА 2- Полевые материалы автора. Экспедиция в Богдановский р-н Грузии. 1989 г. (информант: М.А.Т. 1913 г.р. Гореловка).

ПМА 3 - Полевые материалы автора. Экспедиция в Богдановский р-н Грузии. 1997 г. (информант: М.П. С. 1918 г.р. Гореловка).

ПМА 4 - Полевые материалы автора. Экспедиция в с. Архангельское Чернского р-на Тульской обл. 2003 г. (информанты: П.Ф.Б. 1947 г.р.; А.М.Г. 1911 г.р.; Т.Т.Б. 1947 г.р.; У.В.Г. 1941 г.р. Гореловка).

ПМА 5 - Полевые материалы автора. Экспедиция в с. Архангельское Чернского р-на Тульской обл. 2005 г. (информанты: Д.П.М. 1935 г.р.; А.А.Б. 1937 г.р. Гореловка).

ПМА 6 - Полевые материалы автора. Экспедиция в пос. Мирный Клетнянского р-на Брянской обл. 2009 г. (информанты: Л.Ф.В. 1950 г.р.; М.П.К. 1954 г.р. Гореловка).

ПМА 7 - Полевые материалы автора. Экспедиция в с. Славянка Кедабекского р-на Азербайджана. 2010 г. (информанты: Г.Т.С. 1948 г.р.; А.Н.П. 1942 г.р.; В.Г.А. 1935 г.р.).

ПМА 8 - Полевые материалы автора. Экспедиция в хут. Петровское Целинского р-на Ростовской обл. 2010 г. (информант А.А.Р. 1941 г.р.).

ПМА 9 - Полевые материалы автора. Экспедиция в с. Архангельское Чернского р-на Тульской обл. 2013 г. (информанты: П.Н.К. 1947 г.р.; А.В.З. 1924 г.р.; П.Ф.Б. 1947 г.р.; А.А.Б. 
1937 г.р.; М.К.Т. 1934; А.Е.К. 1927 г.р Гореловка; П.И.Б. 1948 г.р. Ефремовка; Т.И.С. 1946 г.р. Калинино).

ПМА 10 - Полевые материалы автора. Экспедиция в пос. Малый Снежеток, мкр. Новый Первомайского р-на Тамбовской обл. 2014 г. (информанты: Л.В.А. 1935 г.р.; Н.С.К. 1969 г.р. Т.С.Ч. 1964 г.р.. Н.К.С. 1954 г.р. Гореловка; И.А.С. 1948 г.р. Орловка).

ПМА 11 - Полевые материалы автора. Экспедиция в Ниноцминдский р-н Грузии. 2014 г. (информанты: Л.В.Т. 1956 г.р. Орловка; Р.И.С. 1968 г.р. Гореловка. Н.К.С. 1954 г.р. Гореловка).

ПМА 12 - Полевые материалы автора. Петербург 2019 г. (информант А.В.М. 1933 г.р. Богдановка).

РГАДА - Российский государственный архив древних актов. Ф. 7. Оп.2. Д. 2287. Л. 43 об.

РГИА - Российский государственный исторический архив. Ф. 797. Оп. 87. Д. 32. Л. 3 об.

\section{Inikova, Svetlana A.}

"They know, they fear, but they never discuss": witchcraft among the Transcaucasian Doukhobors

Based on field material collected among the Transcaucasian Doukhobors, the article examines the "witchcraft" discourse that was formed in the sect over the two centuries, which the Dukhobors have lived in isolation from the Russian people. The contradiction between the folk tradition that they brought from their places of origin, where they lived among the Orthodox in Russia, and the religious doctrine that did not allow the sons of God to contact with evil force, caused the topic of witchcraft to be forced to the periphery of the cultural field and never be openly discussed. The paper examines traditional complexes of folklore stories that have survived in the Doukhobors environment to the present day, and draws attention to widely known stories that were unacceptable in their community. Although there were no people among the Dukhobors who were actually engaged in witchcraft practices, the article shows the mechanisms of "creating" the image of a sorcerer. The need for such people was exhausted by the desire of the villagers to hold them responsible for problems and misfortunes.

Key words: Doukhobors, religious teaching, witchcraft, folklore image, Russian mythological tradition 